\title{
UN CRUCIFICADO ATRIBUIBLE AL ESCULTOR JESUITA Domingo Beltrán de OTAZu (I535-I590)
}

\section{A Crucificate attribuited to the jesuite sculptor Domingo Beltrán de Otazu (1535-1590)}

\section{Javier Baladrón Alonso ${ }^{1}$}

Recibido: 2-5-2021

Aceptado: 20-7-2021

\section{Resumen}

En el monasterio de San Quirce y Santa Julita se conservó hasta su cierre en 2018 una magnífica escultura de un Crucificado que por sus característicos estilemas puede ser adjudicado al notable escultor renacentista jesuita Domingo Beltrán de Otazu. Su hallazgo presenta un doble interés tanto por su atribución al referido maestro como por el hecho de que ya en vida su fama se sustentó en la ejecución de imágenes de Cristo Crucificado.

Palabras clave: Compañía de Jesús, Domingo Beltrán de Otazu, escultura, Renacimiento, siglo XVI.

\section{Abstract}

In the monastery of San Quirce y Santa Julita was preserved until its closure in 2018 a magnificent sculpture of a Crucified One that, due to its characteristic styles, can be attributed to the notable Renaissance Jesuit sculptor Domingo Beltrán de Otazu. His finding is of two interest, both because of its attribution to the aforementioned master and because of the fact that even in his lifetime his fame was based on the execution of images of Christ Crucified.

Keywords: Society of Jesus, Domingo Beltrán de Otazu, sculpture, Renaissance, 16th century.

1 Investigador independiente. balilla19@hotmail.com y JavierBaladronAlonso@,outlook.es 


\section{Domingo Beltrán de Otazu, un eminente escultor de Crucifijos}

"Fue natural de Vitoria, y aprendió en el siglo, las facultades de la Escultura y Arquitectura en Italia, en que salió muy aventajado, hizo estatuas de grande estimación; y tuvo singular eminencia, en las efigies de Cristo Crucificado, como se califica, en las que hoy se ven con admiración [...] con tan extremada perfección, que todos los Artífices, le daban la primacía, murió por los años 1590, ya de crecida edad"2. Con esta escueta reseña recoge Antonio Palomino (1655-1726) en sus Vidas de los pintores y estatuarios eminentes españoles (1724) la primera referencia biográfico-artística del religioso jesuita y eminente escultor renacentista Domingo Beltrán de Otazu, una de las figuras más enigmáticas de la plástica española del Quinientos y, en palabras de Rodríguez G. de Ceballos, "el primero en fecha de nuestros escultores clasicistas del último tercio del siglo XVI"3.

A finales de esa misma centuria el ilustrado e historiador del arte Juan Agustín Ceán Bermúdez (1749-1829) se limitó a repetir en su Diccionario histórico de los más ilustres profesores de las Bellas Artes en España $(1800)^{4}$ lo dicho por Palomino, añadiendo apenas la fecha de su ingreso en la Compañía de Jesús. Hubo que esperar a 1959 para que el jesuita y eminente historiador del arte Alfonso Rodríguez G. de Ceballos aportara numerosas novedades acerca de su biografía y de su producción artística en el artículo «Nuevos datos documentales sobre el escultor Domingo Beltrán» ${ }^{5}$. Desde entonces poco se ha avanzado en su conocimiento más allá de las diversas hipótesis que se han vertido acerca de su posible formación.

Nacido en Vitoria a comienzos de $1535^{6}$, Domingo Beltrán está considerado como uno de los mejores escultores que trabajaron en la Corona de Castilla en la segunda mitad del siglo XVI. Se desconoce el maestro o maestros bajo los que transcurrió su aprendizaje. Azcárate propuso que su formación acaecería en Italia "ya que no se percibe relación directa con ninguno de los talleres castellanos anteriores"'. Sin embargo, este extremo fue descartado por el padre Ceballos, que demostró que la estancia en Italia "por más que anhelada y afanosamente buscada no se verificó" hasta después de su ingreso en la orden, marchando a Roma unos meses entre los años 1569-1570 ${ }^{8}$. Este hecho le resultó desconcertante por cuanto no encontraba explicación a dónde y con quién pudo aprender ese clasicismo italianizante que se refleja en su obra previa al viaje a la Ciudad Eterna, puesto que se muestra "independiente, por una parte, del ciclo escurialense y totalmente aislado de sus coetáneos nacionales... y su aislamiento más extraño, a fuer de solitario" . Por su parte, Camón Aznar, que

2 PALOMINO DE CASTRO Y VELASCO, A. Museo pictórico y escala óptica. Tomo III. Las vidas de los pintores y estatuarios eminentes españoles. Londres: Imprenta de Hernrique Woodfall, 1744, p. 16.

3 RODRÍGUEZ G. DE CEBALlOS, A. Nuevos datos documentales sobre el escultor Domingo Beltrán. Archivo Español de Arte, 1959, n. ${ }^{\circ} 128$, tomo 32, p. 281.

4 CEÁN BERMÚDEZ, J. A. Diccionario histórico de los más ilustres profesores de las Bellas Artes en España. Tomo I, A-C. Madrid: Imprenta de la viuda de Ibarra, 1800, p. 126.

5 RODRÍGUEZ G. DE CEBALLOS. ref. 3, pp. 281-294.

6 RODRÍGUEZ G. DE CEBALLOS. ref. 3, p. 282.

7 AZCÁRATE RISTORI, J. M. de. Ars Hispaniae Tomo XIII. Escultura del siglo XVI. Madrid: Plus Ultra, 1958, p. 353.

8 RODRÍGUEZ G. DE CEBALLOS. ref. 3, p. 286.

9 Ibidem. 
definió su estilo como de un "clasicismo espontáneo", encontró que "su arte se halla arraigado en el Renacimiento plateresco, con influjo de Picart y de Gregorio Pardo", e incluso observó ciertos recuerdos "de Balmaseda y de contrappostos romanos"10. Su arte, que también se ha creído "enraizado en los últimos maestros expresivistas de su región norteña", evolucionó "hacia un clasicismo de gran corrección a causa de la estancia del artista en Roma" "11.

Ya antes de su ingreso en la Compañía de Jesús el 21 de abril de 1561 en Alcalá de Henares (Madrid $)^{12}$ debía de gozar de una notable fama como escultor -el 1 de mayo, el padre José de Acosta escribió una carta al general Diego Laínez en la que expresaba de manera diáfana el prestigio que por entonces disfrutaba Beltrán ${ }^{13}$-, aunque este hecho contrasta enormemente con la ausencia absoluta de obras de este primer periodo en el que tan solo cabría incluir el Cristo atado a la columna (ca. 15551561) en alabastro situado en el ático del sepulcro de don Juan de Rojas y doña María Sarmiento, primeros marqueses de Poza, en el palentino convento de San Pablo, obra asignada al escultor por Manuel Gómez Moreno ${ }^{14}$. Tras su ingreso en la Orden, en la que llegaría a desempeñar el cargo de coadjutor, la casi totalidad de su producción estuvo destinada a establecimientos jesuíticos repartidos por buena parte de la península: Medina del Campo, Madrid, Murcia, Toledo y Alcalá de Henares. De esta forma, sus continuos traslados a estas poblaciones se debieron casi exclusivamente a la necesidad que tuvo la Compañía de emplearle en las tareas de amueblamiento que por entonces se estaban llevando a cabo en los diferentes colegios que se acababan de erigir o que aún se estaban construyendo. Así, para ellos labraría esculturas, sepulcros y retablos, de ahí que en algunas ocasiones los documentos también se refieran a él como ensamblador.

Tras pasar dos años en Alcalá de Henares marchó a Medina del Campo en 1563 para finalizar su noviciado y realizar la segunda probación. Aquí, en el Colegio de San Pedro y San Pablo (actual iglesia de Santiago el Real), que ejerció las funciones de noviciado jesuita desde que en 1563 fuera trasladado desde Simancas ${ }^{15}$, permaneció hasta la primavera de 1569 y en él dejó las primeras obras que le tenemos documentadas. Consta por el padre Juan Bonifacio ("Noster quidam statuarius lígneas tres imagines appositas admodum confecit, quibus templum exornetur") que al menos labró tres imágenes en el periodo comprendido entre los años 1563-1565 ${ }^{16}$. Todos los investigadores coinciden en que dos de estas esculturas serán las que presiden los retablos colaterales del templo: Jesús atado

10 CAMÓN AZNAR, J. Summa Artis: historia general del arte, XVIII. La escultura y la rejería españolas del siglo XVI. Madrid: Espasa-Calpe, 1981, pp. 367-368.

11 SEBASTIÁN LÓPEZ, S., GARCÍA GAÍNZA, M. C. y BUENDÍA, J. R. Historia del Arte Hispánico III: El Renacimiento. Madrid: Alhambra, 1980, p. 156.

12 CEÁN BERMÚDEZ. ref. 4, p. 126.

13 "En casa ha entrado un hermano que en obra de imaginería y talla es extremadamente diestro, el cual, ofreciéndole otros muy principal partido, dijo que más quería servir a la Compañía, que en otra parte usar de cualquier ventaja". RODRÍGUEZ G. DE CEBALLOS. ref. 3, pp. 282-283.

14 AZCÁRATE RISTORI. ref. 7, p. 353. GÓMEZ MORENO, M. La escultura del Renacimiento en España. Barcelona: Gustavo Gili, 1931. Parrado del Olmo disiente de esta atribución y señala que pudiera deberse a las gubias del escultor palentino Manuel Álvarez (ca. 1517-ca. 1587-1589), discípulo de Alonso Berruguete. PARRADO DEL OLMO, J. M. ${ }^{a}$. Los escultores seguidores de Berruguete en Palencia. Valladolid: Universidad de Valladolid, 1981, p. 245.

15 RODRÍGUEZ G. DE CEBALLOS. ref. 3, p. 282.

16 RODRÍGUEZ G. DE CEBALLOS. ref. 3, p. 283. 


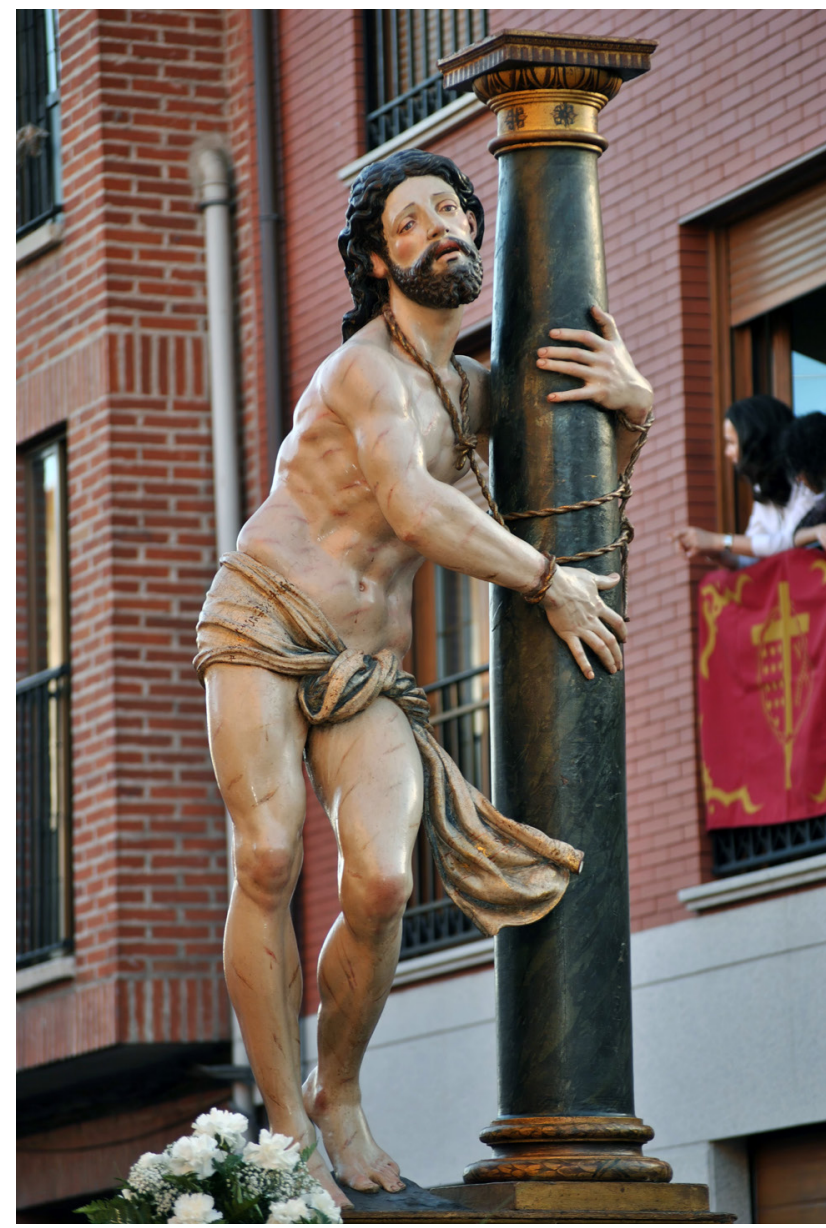

Fig. I. Jesús atado a la columna. Domingo Beltrán de Otazu. Hacia I563I565. Iglesia de Santiago el Real, Medina del Campo (Valladolid). (C) Javier Baladrón Alonso.

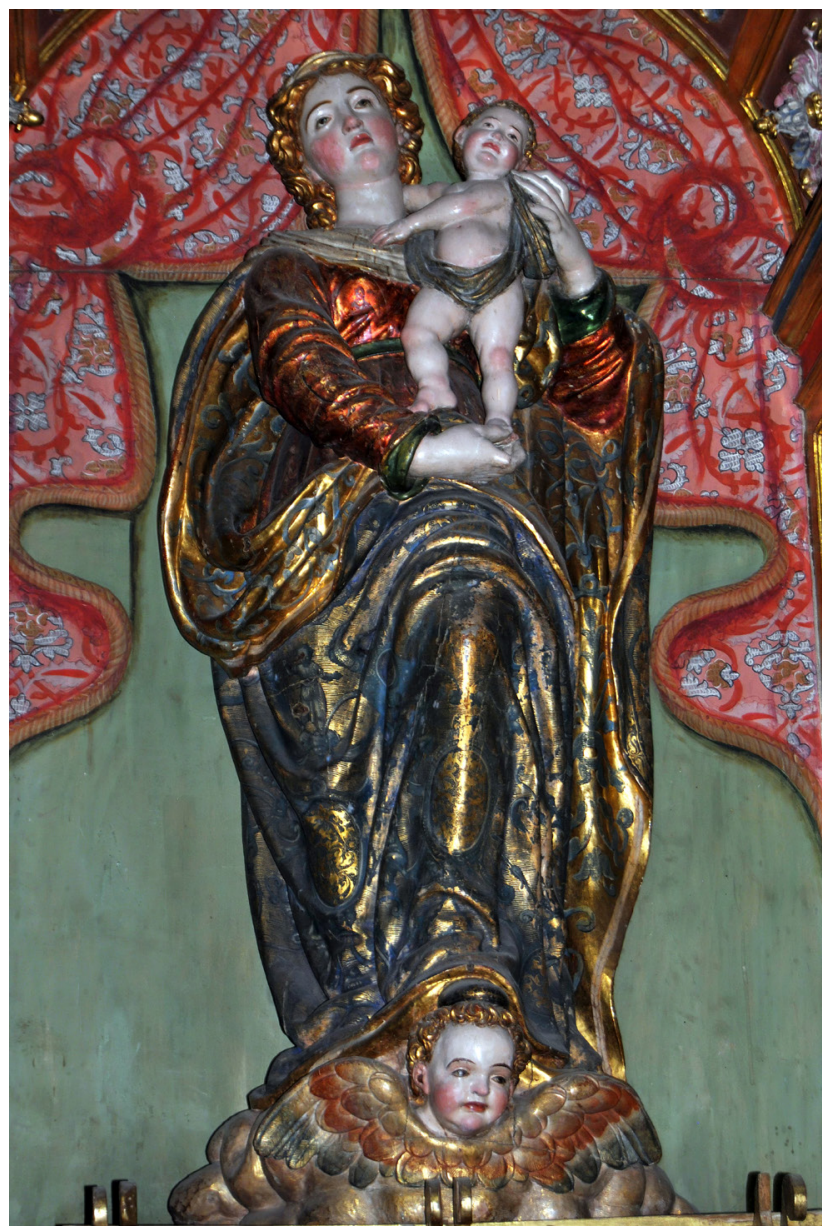

Fig. 2. Virgen con el Niño. Domingo Beltrán de Otazu. Hacia I563-I565. Iglesia de Santiago el Real, Medina del Campo (Valladolid). (C) Javier Baladrón Alonso.

a la columna (evangelio) (Fig. 1) y la Virgen con el Niño (epístola) (Fig. 2), mientras que a la hora de identificar la tercera existen ciertas disensiones, puesto que algunos, como Rodríguez de Ceballos ${ }^{17}$, piensan que se tratará del Crucificado (Fig. 3) que preside el Calvario del ático del retablo mayor -mueble construido con posterioridad (1595), por lo que el Cristo fue reutilizado-, mientras que otros como Arias Martínez, Hernández Redondo y Sánchez del Barrio creen que será el Cristo de la Agonía (Fig. 4), otro portentoso Crucificado existente en el templo y que ha permanecido sin policromar hasta $1955^{18}$. Sea como fuere, la existencia de ambos Crucificados, plenamente asignables a Beltrán, nos permite saber con certeza que no solo hizo tres esculturas para este colegio sino algunas más, puesto que a estas cuatro aún se puede sumar una quinta, ya que en la sacristía antigua existe un Crucificado (Fig. 5) de tamaño menor que el natural y sin policromar que también se le ha sido asignado en base a la completa similitud que guarda con los otros ${ }^{19}$. Según el parecer del padre Ceballos no debió de labrar muchas más obras en este periodo medinense, puesto que "era lento y calmoso en su trabajo, acaso porque repasaba y apuraba sus esculturas hasta el sumo"20.

17 RODRÍGUEZ G. DE CEBALLOS. ref. 3, p. 284.

18 ARIAS MARTÍNEZ, M., HERNÁNDEZ REDONDO, J. I. y SÁNCHEZ DEL BARRIO, A. Semana Santa en Medina del Campo: historia y obras artísticas. Medina del Campo: Junta de Semana Santa de Medina del Campo, 1996, p. 95.

19 Ibidem, p. 128.

20 RODRÍGUEZ G. DE CEBALLOS. ref. 3, p. 283. 


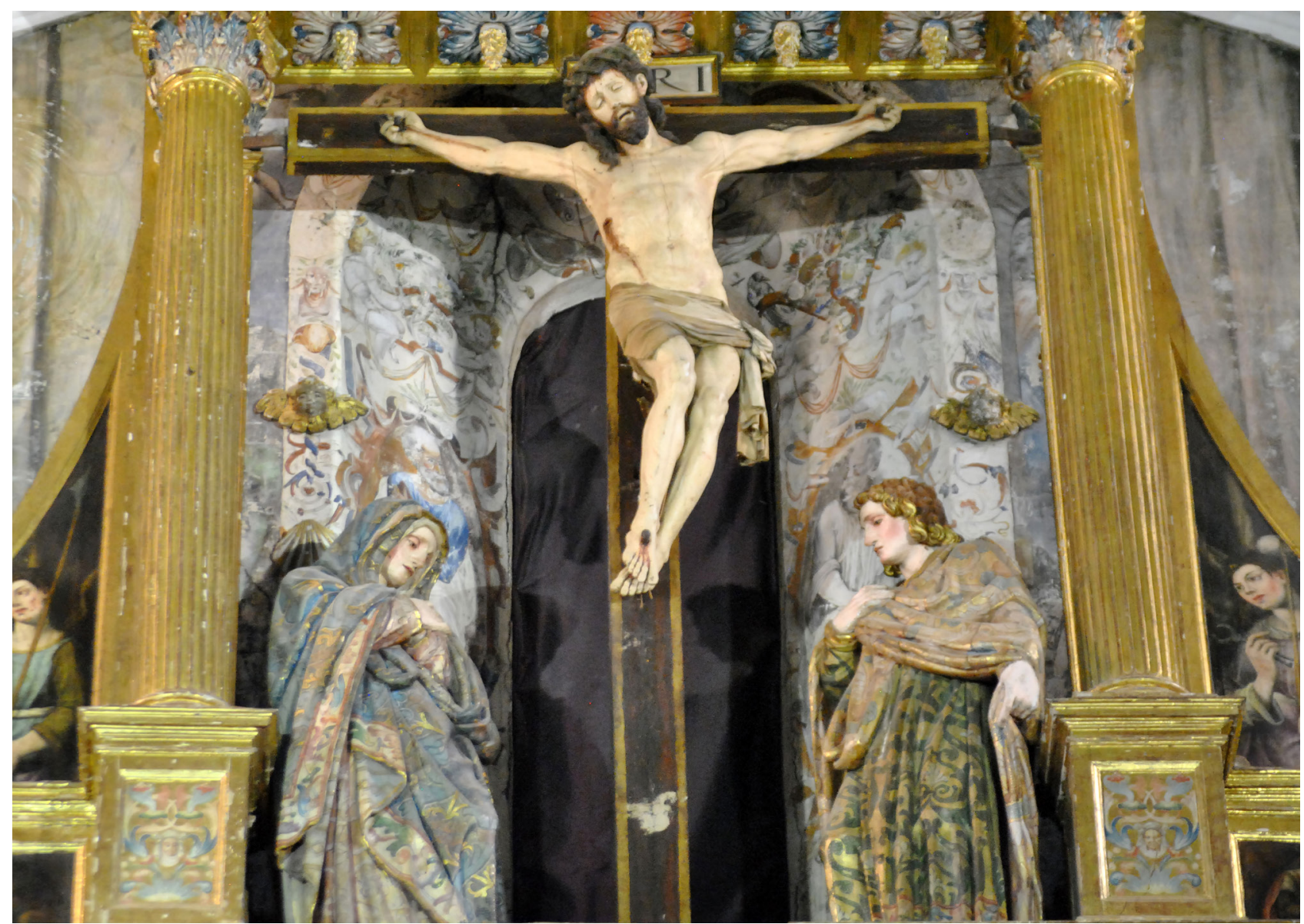

Fig. 3. Crucificado del retablo mayor. Domingo Beltrán de Otazu. Hacia I563-I565. Iglesia de Santiago el Real, Medina del Campo (Valladolid). (C) Javier Baladrón Alonso.

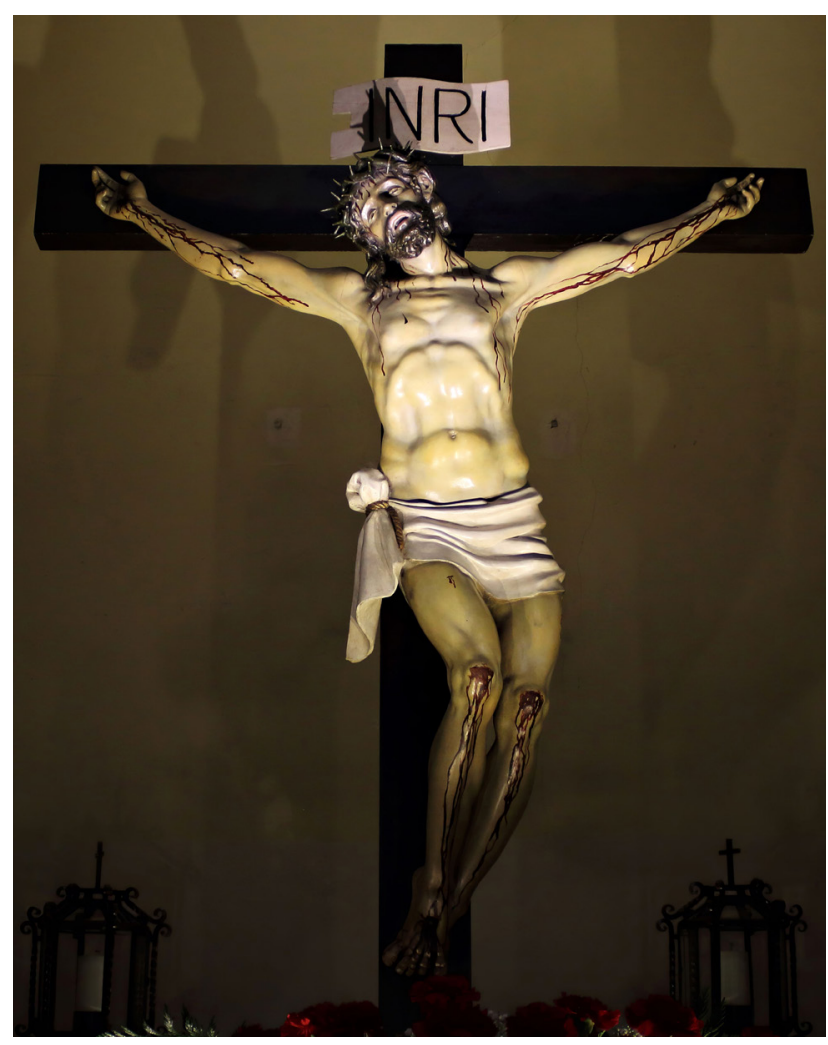

Fig. 4. Cristo de la Agonía. Domingo Beltrán de Otazu. Hacia I5631565. Iglesia de Santiago el Real, Medina del Campo (Valladolid). (C) Javier Baladrón Alonso.

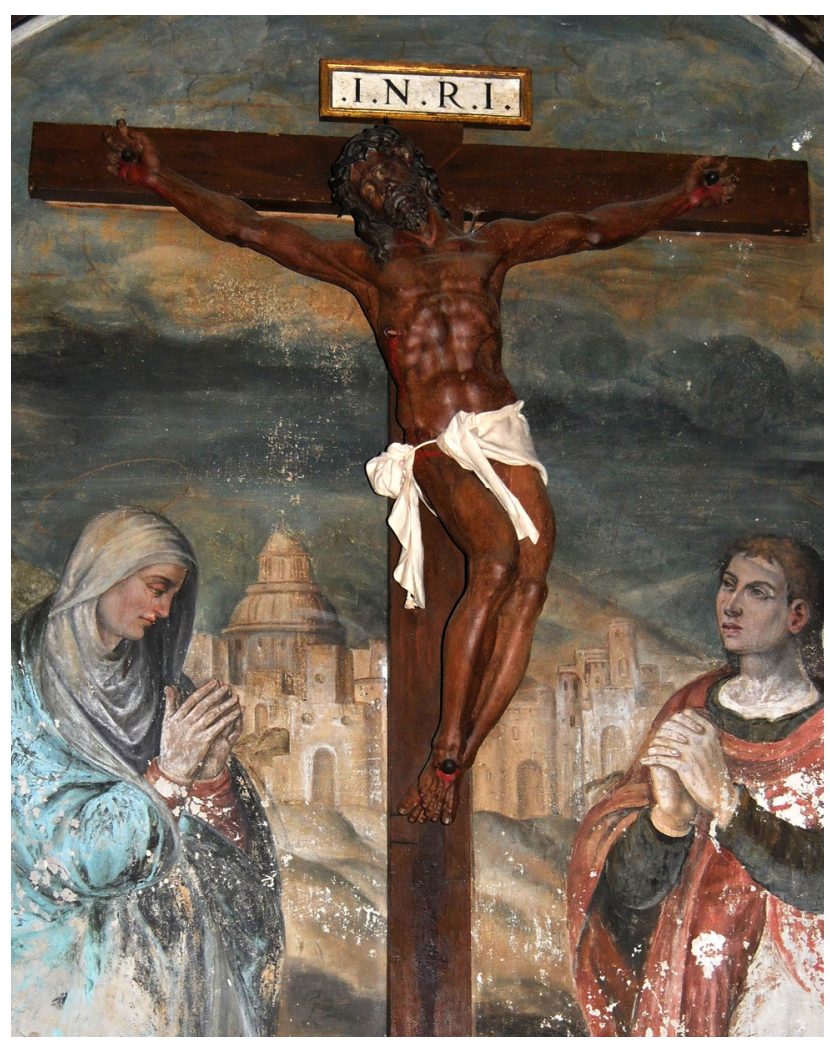

Fig. 5. Crucificado de la sacristía. Domingo Beltrán de Otazu. Hacia I5631565. Iglesia de Santiago el Real, Medina del Campo (Valladolid). (C) Javier Baladrón Alonso. 
El 30 de junio de 1568 el escultor escribió al general de la Compañía, el futuro san Francisco de Borja $^{21}$, para solicitarle permiso para viajar a Italia a perfeccionar su arte. La respuesta fue positiva y el escultor pudo cumplir su sueño de partir a Roma y conocer de cerca la obra de Miguel Ángel y sus discípulos. En la Ciudad Eterna se mantuvo durante algo más de un año, desde la primavera de 1569 hasta el otoño de 1570, tras lo cual regresó a España vía Génova-Barcelona ${ }^{22}$. A pesar de que estuvo a punto de recalar en $\mathrm{Cuenca}^{23}$, para cuyo colegio jesuítico se tenía proyectado realizar el retablo mayor y se había barajado para su ejecución el nombre de Beltrán, se estableció en Murcia entre 1570-1576. Allí pudo demostrar por primera vez cuanto había influido el periplo romano en su estilo. Así, demostró una belleza más refinada, el clasicismo de sus formas se acentuó llegando a ser más puras, delicadas y equilibradas; y, asimismo, transitó hacia un canon más estilizado. Además, se percibe en su plástica la introducción de un lenguaje "heredado de Miguel Ángel” que se patentiza en la "monumental corporeidad y en las evocaciones clásicas de sus rostros"24.

En el jesuita colegio de San Esteban de Murcia se hizo cargo de la labra del retablo mayor -cuyas esculturas desaparecieron casi por completo en un incendio acaecido a finales de $1931-$ y del Sepulcro del obispo Esteban Almeida, prelado que costeó el colegio, el retablo mayor, la reja y su propio sepulcro. También para este mismo templo ejecutó las elegantes y clasicistas estatuas de San Lucas y Santa Catalina ubicadas en los intercolumnios de la portada ${ }^{25}$, así como un Crucificado actualmente conservado en el Museo de la iglesia de San Juan de Dios ${ }^{26}$ (Fig. 6) y el Crucificado de la Misericordia (Fig. 7) que hoy en día se custodia en la iglesia de San Miguel, si bien se piensa que estas dos últimas imágenes pudo labrarlas durante su segunda etapa murciana (1581-1584) ${ }^{27}$, estancia propiciada por las autoridades jesuitas para evitar que Beltrán se dispersara y pudiera abandonar la Orden para así trabajar para la Corte, desde la que le habrían llegado cantos de sirena. Cristóbal Belda y Elías Hernández señalan que la presencia de Beltrán en Murcia resultó decisiva para dar "un nuevo rumbo a la escultura por la renovadora intensión del Clasicismo aprendido y la plenitud plástica de sus corpulentas figuras. La fuerza con que el Clasicismo, un clasicismo de raíz helenizante se presenta bajo una forma majestuosa de expresión, quedaba amparado por un sentimiento similar en la obra del jesuita"28.

Sus continuos traslados se incrementaron aún más a lo largo de sus últimos 15 años de vida. Tal es así que tras abandonar Murcia en 1576 se dirigió a Madrid (1576-1581), regresó a Murcia (15811584), volvió a la Villa y Corte (1584-1587) y, finalmente, recaló en Alcalá de Henares en 1587 para

21 RODRÍGUEZ G. DE CEBALLOS. ref. 3, p. 285.

22 RODRÍGUEZ G. DE CEBALLOS. ref. 3, p. 286.

23 RODRÍGUEZ G. DE CEBALLOS. ref. 3, p. 287.

24 Belda NAVARRO, C. y HeRnÁNDEZ ALBADALEJO, E. Arte en la Región de Murcia. De la Reconquista a la Ilustración. Murcia: Comunidad Autónoma de la Región de Murcia, 2006, p. 185.

25 Ibidem, p. 185.

26 Museo Región de Murcia [en línea] [consulta 9 de abril de 2021]. Disponible en: https://www.museosregiondemurcia.es/conjunto-monumental-san-juan-de-dios/el-edificio/el-museo

27 RODRÍGUEZ G. DE CEBALLOS. ref. 3, p. 293.

28 BELDA NAVARRO, C. y HERNÁNDEZ ALBADALEJO, E. ref. 24, p. 187. 


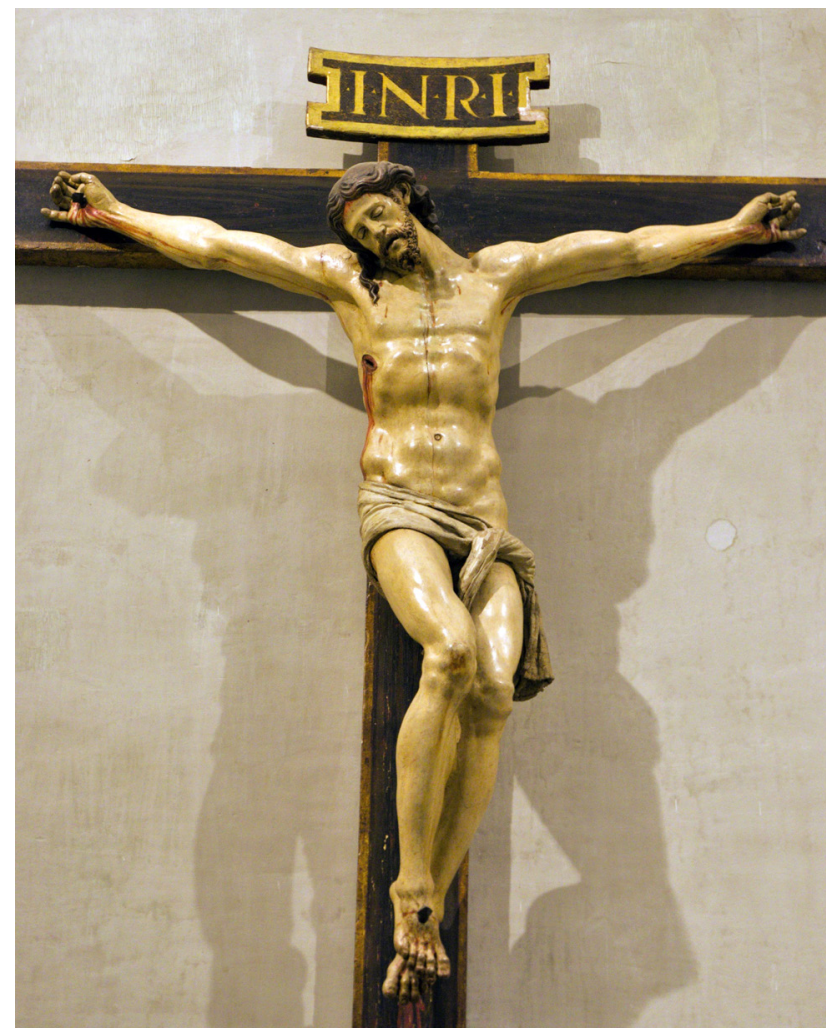

Fig. 6. Crucificado. Domingo Beltrán de Otazu (atrib.). Hacia I58II584. Museo de la iglesia de San Juan de Dios, Murcia. (C) Marta Masiá.

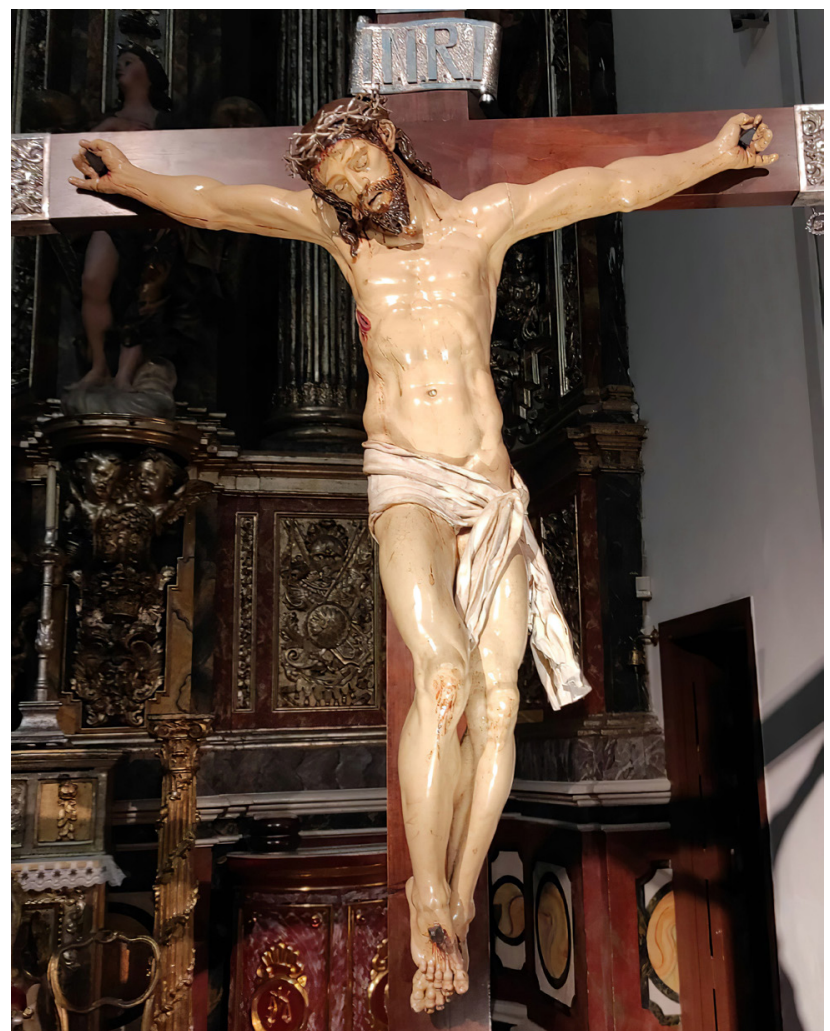

Fig. 7. Cristo de la Misericordia. Domingo Beltrán de Otazu (atrib.). Hacia I58I-I584. Iglesia de San Miguel, Murcia. C Marta Masiá.

morir allí en 1590. Durante este último periodo las obras que se le tienen documentadas son escasas. En Madrid trabajó fundamentalmente para el jesuita Colegio Imperial labrando, al menos, dos Crucificados: uno para la capilla del Cristo y otro para la bóveda de la Congregación de los Abogados ${ }^{29}$, el segundo de los cuales no se llegó a policromar, práctica que debió de ser bastante habitual en Beltrán, puesto que existen más ejemplos entre sus Crucificados. Durante su segunda etapa madrileña, en 1587 acometió la ampliación del retablo mayor del citado Colegio Imperial, al que además debió de "añadirle otras piezas" 30; así como la construcción de dos retablos laterales -en uno de los cuales piensa Azcárate que pudo estar dispuesta la Virgen del Buen Consejo ${ }^{31}$ - que fueron dorados y policromados en 1589 por el pintor Francisco López ${ }^{32}$.

A su llegada a Madrid debió de llamar la atención del rey Felipe II que sopesó la posibilidad de encargarle algún trabajo para el Monasterio de San Lorenzo de El Escorial, pero finalmente esa tentativa no llegaría a materializarse ${ }^{33}$. Que conoció y quizás mantuvo amistad con el arquitecto de aquel inmenso complejo monacal y palaciego, Juan de Herrera (1530-1597), lo demuestra el hecho de que

29 "Tuvo singular eminencia, en las efigies de Cristo Crucificado, como se califica, en las que hoy se ven con admiración, en este Colegio Imperial: como son la de la Capilla del Santísimo Cristo, en la Iglesia; y otra, en la bóveda de la congregación de los Señores Abogados, que está sin encarnar: y cierto que parece de Miguel Ángel”. PALOMINO DE CASTRO Y VELASCO. ref. 2, pp. 16-17.

30 CEÁN BERMÚDEZ. ref. 4, p. 126; RODRÍGUEZ G. DE CEBALLOS. ref. 3, p. 291.

31 AZCÁRATE RISTORI. ref. 7, p. 354.

32 RODRÍGUEZ G. DE CEBALLOS. ref. 3, p. 291.

33 Señala Ceán: "Palomino dice que Felipe II celebraba su mérito, y que deseaba llevarle al Escorial para que trabajase algunas estatuas, lo que sospecho no se hubiese verificado por su edad y porque no se conserva ninguna de su mano en aquel monasterio". CEÁN BERMÚDEZ. ref. 4, p. 126. 
entre los bienes que pertenecieron a su esposa se encontraban un "Crucifijo pequeño de boj, con su peana, hecho por el Padre Beltrán de la Compañía de Jesús..., un Niño Jesús arrimado a un peñasco, durmiendo, y un San Juan de barro cocido, de altura de una tercia, hecho por el Padre Beltrán y lo mismo el Niño Jesús" ${ }^{34}$. Señala Rodríguez G. de Ceballos que, además del Crucificado, otra de las especialidades de Beltrán fue la ejecución de pequeñas imágenes del Niño Jesús, las cuales le dieron tanta fama que llegaron a solicitárselas desde Nueva España ${ }^{35}$. Señala Azcárate que estos "temas constituyen un precedente de importancia respecto a las populares creaciones barrocas" 36 . Como observamos, Beltrán poseyó suma destreza en el desempeño de su oficio, puesto que labró, modeló y talló mármol, alabastro, tela encolada, barro cocido y madera con igual maestría. Parece ser que también realizó en barro unos desaparecidos bustos de San Ignacio para el Colegio Imperial de Madrid y para el Colegio Máximo de la Compañía en Alcalá de Henares $^{37}$, ciudad en la que, además, se le asigna el imponente Crucificado puesto bajo la advocación del Cristo de los Doctrinos, que es considerado por Camón Aznar como "obra de gran sabiduría, de modelado anatómico y con una solemnidad y grandeza que anticipa los grandes Crucifijos de nuestro barroco" $" 38$. También labraría en esta última época otro crucificado, el Cristo de la Buena Muerte (Fig. 8), para la iglesia de los jesuitas de Toledo ${ }^{39}$, en donde Beltrán llegaría al culmen del virtuosismo y en el que mezcla la delicadeza de ejecución con un canon esbelto y un fuerte patetismo ${ }^{40}$.

$\mathrm{Su}$ última obra conocida, e inacabada

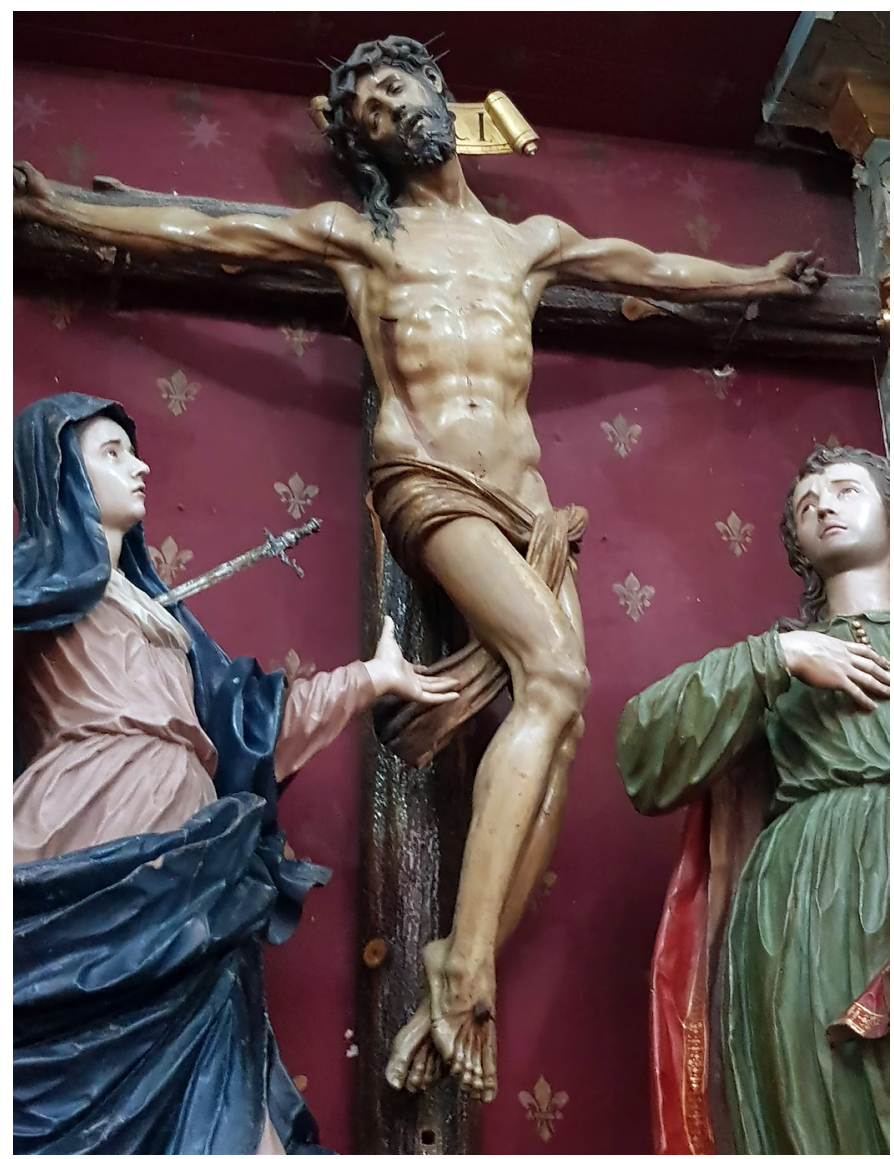

Fig. 8. Cristo de la Buena Muerte (atrib.). Hacia I576-I587. Iglesia de San Ildefonso, Toledo. (C) Teresa Palacios. por su fallecimiento el 27 de abril de 1590, fue el retablo mayor del Colegio Máximo de Alcalá de Henares, conjunto del que "debieron quedar algunas piezas sueltas, una de ellas, acaso, el relieve del Camino del Calvario que estuvo en la cárcel de Alcalá, y, desde luego, un Crucifijo que vio en la nueva iglesia comenzada en 1604 el P. Cristóbal

34 RODRÍGUEZ G. DE CEBALLOS. ref. 3, p. 293.

35 RODRÍGUEZ G. DE CEBALLOS. ref. 3, p. 294.

36 AZCÁRATE RISTORI. ref. 7, p. 353.

37 AZCÁRATE RISTORI. ref. 7, p. 354.

38 CAMÓN AZNAR. ref. 10, p. 368.

39 AZCÁRATE RISTORI. ref. 7, p. 353.

40 CAMÓN AZNAR. ref. 10, p. 368. 


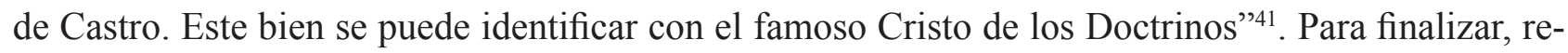
cientemente se le ha atribuido un Crucificado en el Museo Lázaro Galdiano de Madrid ${ }^{42}$, que a pesar de su relativo parecido con el Cristo de los Doctrinos creo que no puede adjudicársele si comparamos sus rasgos faciales, el tratamiento anatómico y el paño de pureza que exhibe con los presentes en sus otras esculturas de Cristo en la cruz.

\section{El Crucificado del Monasterio de San Quirce}

Ya hemos visto como la fama de Domingo Beltrán de Otazu se sustenta fundamentalmente en su habilidad para labrar Crucificados, tal es así que estos conforman la mayoría de su producción artística. De los once ejemplares que se le tienen documentados o atribuidos - tres en la iglesia del antiguo colegio de los Santos Pedro y Pablo de Medina del Campo (ca. 1563-1565), el desaparecido del retablo mayor del colegio de San Esteban de Murcia (ca. 1570-1575), los dos desaparecidos del Colegio Imperial de Madrid (ca. 1576-1581), el de la iglesia de San Ildefonso de Toledo (ca. 1576-1587), los de las iglesias de San Juan de Dios y de San Miguel de Murcia que proceden del templo de San Esteban (ca. 1581-1584), el de los Doctrinos de Alcalá de Henares (ca. 1587-1590), y el del Museo Lázaro Galdiano (ca. 15761586) - tres han desaparecido (los dos de Madrid y el del retablo de San Esteban de Murcia), tres no se llegaron a policromar (el de la Agonía y el de la sacristía del colegio de Medina del Campo, y el de la Congregación de los Abogados del Colegio Imperial de Madrid) y dos mantienen una atribución un tanto dudosa (el Cristo de los Doctrinos de Alcalá de Henares y el del Museo Lázaro Galdiano). En su mayoría se trata de grandes Crucificados con semblante sereno que han sido concebidos en ese justo momento que separa la vida de la muerte en el que no se puede preci-

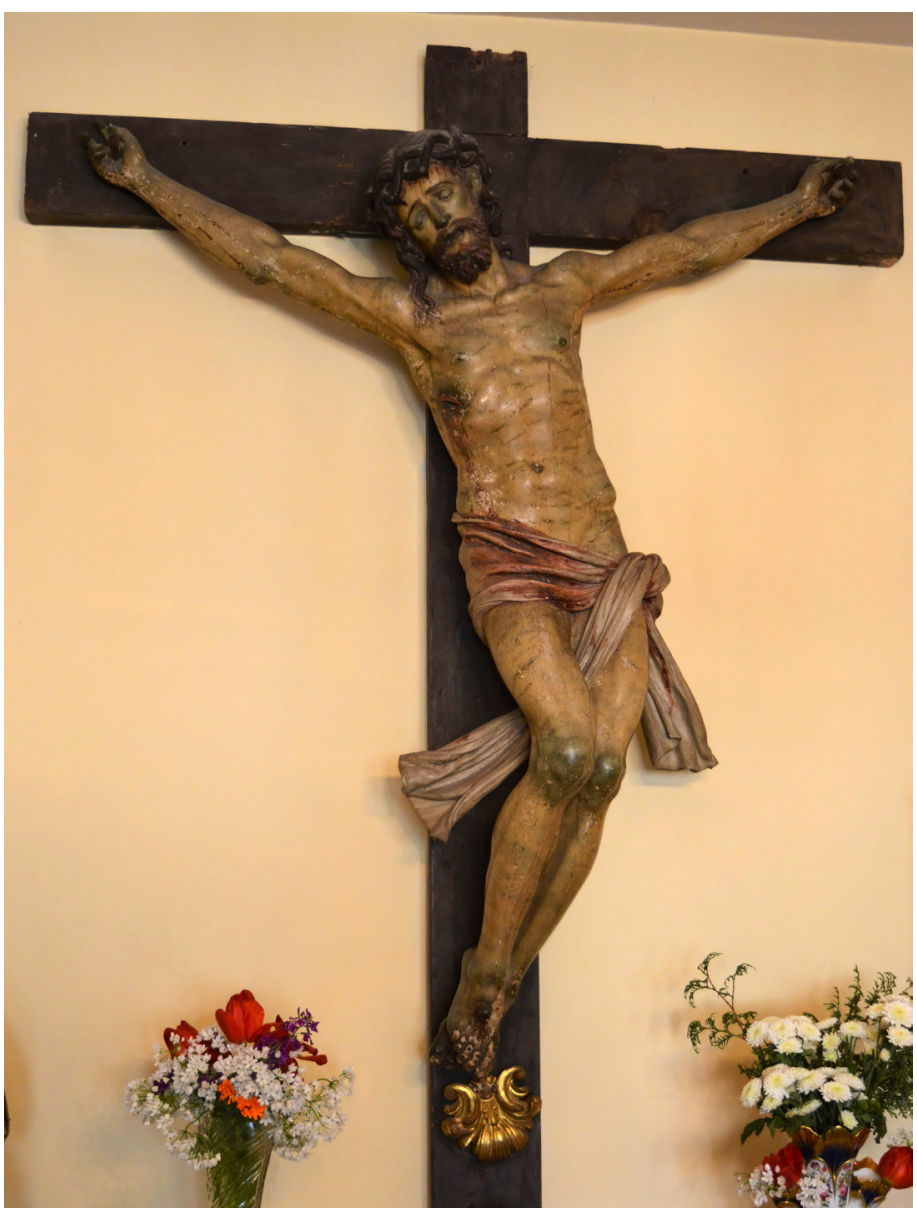

Fig. 9. Crucificado. Domingo Beltrán de Otazu (atrib.). Hacia I56I-I568. Monasterio de las Huelgas Reales, Valladolid. (C) Javier Baladrón Alonso.

41 RODRÍGUEZ G. DE CEBALLOS. ref. 3, p. 294. Algunos notables investigadores como Azcárate desechan la asignación a Beltrán. AZCÁRATE RISTORI. ref. 7, p. 353.

42 Ceres. Red Digital de Colecciones de Museos de España [en línea] [consulta: 9 de abril de 2021]. Disponible en: http://ceres.mcu.es/pages/Main?idt=132559\&inventary=08437\&table=FMUS\&museum=MLGM 
sar si Cristo se encuentra a punto de fallecer o bien acaba de exhalar su último hálito. Todos fueron labrados para colegios o establecimientos jesuitas, con la salvedad del Crucificado del Museo Lázaro Galdiano del que se desconoce su procedencia.

El monumental Crucificado $(178 \mathrm{~cm})$ que asignamos a Domingo Beltrán de Otazu presidió la sala capitular del cisterciense monasterio de San Quirce de Valladolid (Fig. 9) hasta el cierre del mismo por falta de vocaciones en 2018, momento en el que sería trasladado al monasterio de las Huelgas Reales de la misma ciudad por cuanto allí fueron a parar los bienes artísticos que contuvo el clausurado cenobio. Cuando el Crucifijo aún se encontraba en la sala capitular tenía a su lado un busto de Dolorosa de gran tamaño asignado al escultor Antonio de Gautúa (1682-1744). Ambas imágenes fueron reaprovechadas para este espacio, puesto que se trataba de una estancia moderna construida en la década de 1970. Desconocemos el lugar exacto para el que fue labrado el Crucificado y tampoco tenemos ningún testimonio gráfico suyo que nos lo ubique en otro lugar del cenobio. En cambio, sí que se conserva una fotografía en la que el busto aparece dispuesto en un retablo situado a los pies del templo.

La atribución a nuestro escultor parece indudable, pues viene a copiar miméticamente la estética y los estilemas presentes en sus Crucificados, especialmente en los realizados antes de su viaje a Italia, tras el cual, a pesar de que seguirá desarrollando una pauta similar, se percibirá un mayor clasicismo, con unas anatomías más estilizadas y apuradas, además de un movimiento menos impetuoso y unos rostros más afilados. Dos son los elementos en los que se basa la atribución: la cabeza, cuyos rasgos faciales vienen a ser un calco de los existentes en todas sus imágenes cristíferas -así, el rostro emparenta con el de los tres Crucificados y el del Cristo atado a la columna de Medina del Campo, así como con el del Crucificado de Toledo, alejándose un tanto del conservado en Murcia-; y el paño de pureza, que lo concibe de manera sumamente personal, siendo idéntico al de los dos Crucificados de Murcia (el desaparecido y el conservado), al de Toledo, y también al del Cristo atado a la columna de Medina del Campo, si bien en este caso lo ha dispuesto a la inversa.

Llaman la atención los paños de pureza de los tres Crucificados de Medina, puesto que dos de ellos -el del retablo mayor y el del pequeño de la sacristía- son de tela natural, mientras que el del llamado Cristo de la Agonía, a pesar de estar labrado, difiere completamente de la solución adoptada de forma genérica por el escultor, ya que se resuelve con un simple perizonium horizontal anudado en la cadera izquierda; por su parte el del Cristo de la Misericordia de Murcia posee un paño de pureza realizado en tela encolada, lo que nos muestra el magisterio de Beltrán también en este material tan ligero y maleable.

A continuación, reseñaremos los caracteres y estilemas presentes en este Crucifijo de las monjas cistercienses que, como ya hemos señalado, vienen a ser los mismos que exhiben la mayoría de sus Crucificados, si bien en ocasiones introduce ligeras variantes. Cristo aparece clavado en la cruz con tres clavos y sin subpedáneo. A pesar de que por su rostro parece aún vivo, su cuerpo se ha desplomado ya sobre el hombro izquierdo, lo que nos indica que acaba de expirar. Posee un canon clásico en el que el escultor ha plasmado de forma convincente un dramatismo sereno que no se encuentra exento de elegancia formal. La anatomía es poderosa y parece preludiar el Romanismo, aunque sin los excesos musculares de aquel. 


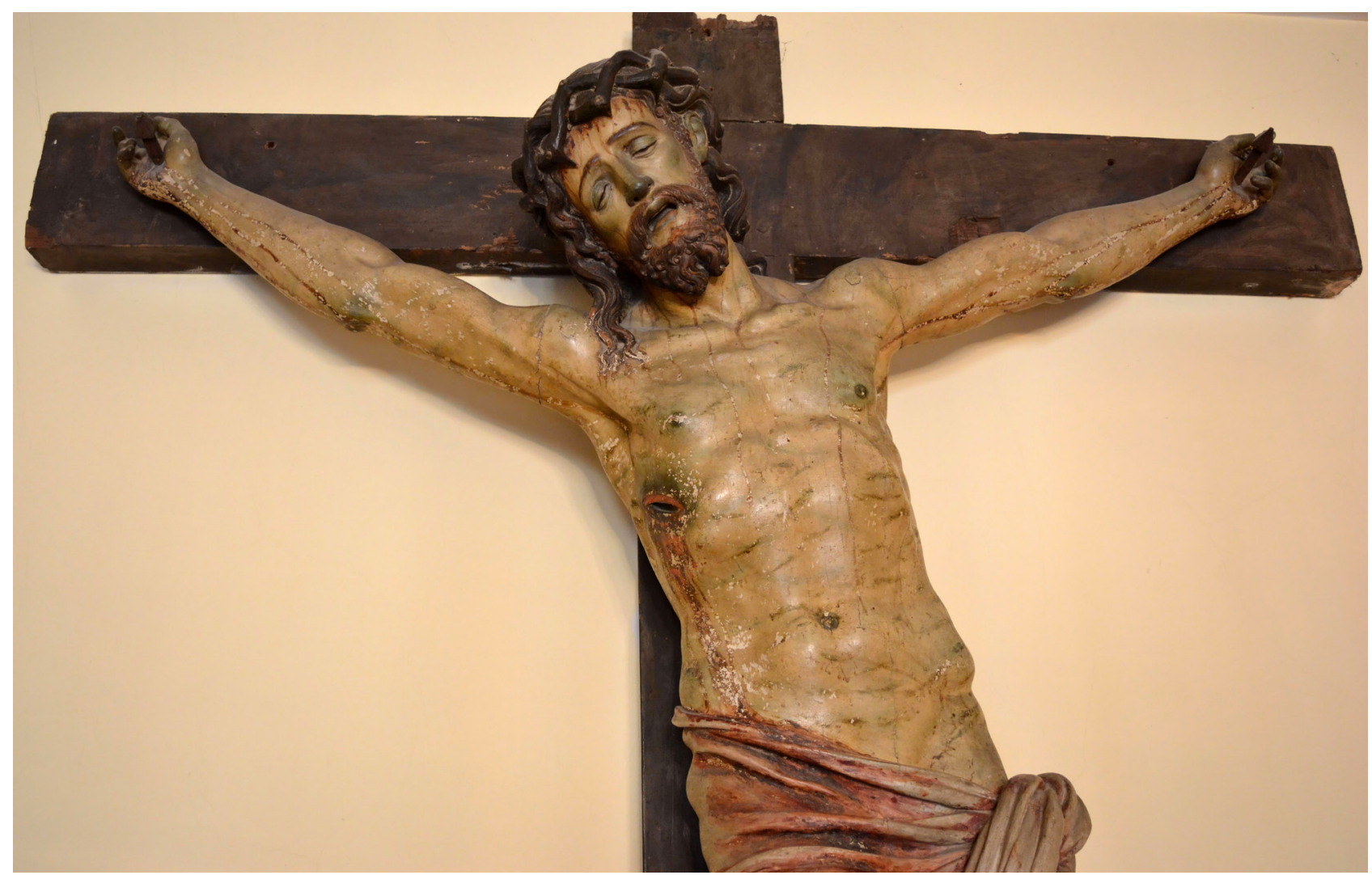

Fig. I0. Detalle del Crucificado. Domingo Beltrán de Otazu (atrib.). Hacia I56I-I568. Monasterio de las Huelgas Reales, Valladolid. (C) Javier Baladrón Alonso.

El cuerpo (Fig. 10) presenta un canon alargado y adopta un suave arqueamiento que traza una helicoidal que dibuja una composición en serpentinata. Muestra un apurado estudio anatómico de gran perfección, además de un modelado mórbido y unas extremidades fibrosas en las que se marcan de manera notable los huesos (clavículas, hombros y rodillas) y los músculos (gemelos, cadera, cuello), encontrándose alguno de ellos aún en tensión, caso de los que componen su axila derecha. Los brazos, que a causa de la muerte ya se han desplomado, son musculosos y exhiben unas manos compuestas por dedos largos, finos y crispados que aún acusan el dolor producido por los clavos. Por su parte, las piernas presentan un notable retorcimiento, disponiendo la izquierda por debajo de la derecha, acrecentando así el dinamismo compositivo. Los pies están superpuestos, traspasados por un único clavo. El cuerpo se encuentra tan solo cubierto por un perizonium que repite en buena parte de sus Crucificados y que pasa por ser una especie de firma del escultor. Se trata de un paño de pureza muy estrecho que se limita a ocultar las partes pudendas, no impidiendo una visión global de su anatomía, de tal forma que incide en ese gusto por el desnudo tan típico del Renacimiento. Anudado en la cadera izquierda, dispone uno de los extremos cayendo horizontalmente por ese mismo lado mientras que el otro lo introduce entre las piernas y ejecuta una curva que finaliza detrás del muslo derecho. El tratamiento es tan realista que en vez de madera parece tela real dispuesta sobre un cuerpo desnudo labrado en su totalidad. El escultor, que semeja la técnica de los paños mojados, dispone abundantes pliegues horizontales de aristas redondeadas que conforman concavidades de diverso tamaño y que en ocasiones se pueden amontonar. La policromía es a pulimento y no incide especialmente en el rastro sanguinolento, concentrándose este en las cinco llagas y en el paño de pureza. 
La cabeza está ladeada hacia la derecha. Su rostro es el de un hombre completamente exhausto que acaba de fallecer, con los ojos a punto de cerrarse y la boca entreabierta, detalle que acrecienta el dramatismo, pero que no pasa de ser un patetismo contenido. La cabeza adquiere un formato ancho y ovalado y presenta unas facciones nobles labradas con exquisita delicadeza. Beltrán ha remarcado especialmente la nariz, los pómulos y las cuencas oculares. Cejas rectas, ojos rasgados y con los párpados caídos, nariz grande y recta con las fosas nasales perforadas y las aletas perfectamente definidas. Bajo ella el surco nasolabial flanqueado por gruesos bigotes simétricos que recuerdan la solución que adoptarán los escultores romanistas. La boca, en cuyo interior se perciben los dientes superiores, es pequeña, recta y con labios carnosos. Peina una cabellera conformada por mechones largos, gruesos y compactos que flanquean el rostro, dejando a la vista la oreja izquierda, y que caen sobre los hombros. La cabeza va tocada por una corona de entrelazo tallada en la propia escultura como fue usual durante el Renacimiento. La barba es bífida y simétrica, compuesta por pequeños bucles que en la zona del mentón se alargan y adoptan formas sinuosas, si bien todos ellos están labrados con sumo virtuosismo.

Por la extremada similitud que posee con los tres Crucificados de Medina del Campo, de los que parece hermano, creemos que su cronología será contemporánea y que, en todo caso, su ejecución acontecería antes del viaje a Italia, es decir, hacia 1561-1568. Desconocemos el origen de este monumental Crucificado. Bien pudo ser donado por algún bienhechor, formar parte de la dote de una monja profesa, ser el obsequio de una abadesa, e incluso haber sido adquirido por la propia comunidad en su momento, o en otro posterior. Debido a que nuestro escultor trabajó de manera casi exclusiva para su propia orden querríamos apuntar la posibilidad de que esta exquisita pieza pudiera haber recalado en el cenobio cisterciense procedente de la cercana Casa Profesa de San Antonio - pues esta era la advocación que tenía en tiempos de Beltrán de Otazu- que habían fundado en 1543 los padres Pedro Fabro y Antonio de $\mathrm{Araoz}^{43}$ a su paso por la ciudad mientras acompañaban "desde Portugal a la princesa doña María, hija del rey don Juan III de aquella corona, que venía a casar con el príncipe don Felipe II del nombre de Castilla, hija del Emperador Carlos V"44. En tal caso la llegada del Crucificado al Monasterio de San Quirce pudo haber tenido lugar tras la expulsión de los jesuitas de España en 1767 pues, como ya dio a conocer Urrea, algunas esculturas fueron concedidas el 20 de octubre de 1770 por el Real Consejo de Castilla a petición del cenobio ${ }^{45}$.

A la problemática sobre su procedencia se añade también la de si Beltrán lo enviaría desde alguna de las ciudades en las que tenemos constatada su presencia -en este caso lo más lógico sería pensar

43 A raíz de la beatificación de Ignacio de Loyola pasaría a denominarse Colegio de San Ignacio, y tras la expulsión de los jesuitas en 1767 su iglesia reuniría las parroquias de San Miguel y San Julián, cuyos primitivos y ruinosos templos se derribarían pocos años después, tomando el nombre de Real Iglesia de San Miguel, San Julián y Santa Basilisa.

44 CANESI, M. Historia de Valladolid (1750). Tomo III. Valladolid: Grupo Pinciano, 1996, p. 239.

45 "Ilustrísimo Señor. El Consejo en vista de instancia de la abadesa del Real monasterio de San Quirce de esa ciudad ha venido, en el extraordinario que celebró en 9 de este mes, en conceder a la Comunidad de Religiosas del mismo monasterio dos Niños de Nápoles, con un Ecce Homo y una Nuestra Señora de los Dolores que están en dos escaparates en la Sacristía del Colegio de San Ignacio que fue de Regulares de la Compañía de esa ciudad para darles culto; en caso de no ser necesarias estas Efigies en la Parroquia ni ofrecerse reparo a V.S.I. con quien se ha de poner de acuerdo ese Comisionado a cuyo efecto se le comunica la orden conveniente". URREA, J. Las esculturas de Villabrille y Ron del Monasterio de San Quirce. Boletín de la Real Academia de Bellas Artes de la Purísima Concepción, . $^{\circ} 36,2001$, p. 138. 
que fuera desde la cercana Medina del Campo- o bien lo labró en la propia Valladolid, lo que plantearía la sugestiva hipótesis de que se hubiera formado en alguno de los talleres abiertos en la ciudad hacia 1550. Quizá no sea descabellado pensar que su adiestramiento hubiera transcurrido a la sombra de los discípulos de Berruguete Francisco Giralte (ca. 1510-1576) o Manuel Álvarez (ca. 1517-ca. 1587/1589) -maestro con el que emparenta la cabeza del Crucifijo de San Quirce que atribuimos a Beltrán-, así podría explicarse el italianismo patente en su obra previa al viaje a Italia, que también pudo conocer gracias a los grabados. 


\section{Bibliografía}

ARIAS MARTÍNEZ, Manuel, HERNÁNDEZ REDONDO, José Ignacio y SÁNCHEZ DEL BARRIO, Antonio. Semana Santa en Medina del Campo: historia y obras artísticas. Medina del Campo: Junta de Semana Santa de Medina del Campo, 1996.

AZCÁRATE RISTORI, José María de. Ars Hispaniae Tomo XIII. Escultura del siglo XVI. Madrid: Plus Ultra, 1958.

BELDA NAVARRO, Cristóbal y HERNÁNDEZ ALBADALEJO, Elías. Arte en la Región de Murcia. De la Reconquista a la Ilustración. Murcia: Comunidad Autónoma de la Región de Murcia, 2006.

CAMÓN AZNAR, José. Summa Artis: historia general del arte, XVIII. La escultura y la rejería españolas del siglo XVI. Madrid: Espasa-Calpe, 1981.

CANESI, Manuel. Historia de Valladolid (1750). Valladolid: Grupo Pinciano, 1996.

CEÁN BERMÚDEZ, Juan Agustín. Diccionario histórico de los más ilustres profesores de las Bellas Artes en España. Tomo I, A-C. Madrid: Imprenta de la viuda de Ibarra, 1800.

GÓMEZ MORENO, Manuel. La escultura del Renacimiento en España. Barcelona: Gustavo Gili, 1931.

PALOMINO DE CASTRO Y VELASCO, Antonio. Museo pictórico y escala óptica. Tomo III. Las vidas de los pintores y estatuarios eminentes españoles. Londres: Imprenta de Hernrique Woodfall, 1744.

PARRADO DEL OLMO, Jesús María. Los escultores seguidores de Berruguete en Palencia. Valladolid: Universidad de Valladolid, 1981.

RODRÍGUEZ G. DE CEBALlOS, Alfonso. Nuevos datos documentales sobre el escultor Domingo Beltrán. Archivo Español de Arte, 1959, n. ${ }^{\circ}$ 128, tomo 32, pp. 281-294.

SEBASTIÁN LÓPEZ, Santiago, GARCÍA GAÍNZA, María Concepción y BUENDÍA, José Rogelio. Historia del Arte Hispánico III: El Renacimiento. Madrid: Alhambra, 1980.

URREA, Jesús. Las esculturas de Villabrille y Ron del Monasterio de San Quirce. Boletín de la Real Academia de Bellas Artes de la Purísima Concepción, 2001, n. ${ }^{\circ}$ 36, pp. 137-138. 